\title{
Collective memories on the 2010 European debt crisis
}

European Union Politics $0(0) \mathrm{I}-23$ (C) The Author(s) 2021

(c) (1)

Article reuse guidelines: sagepub.com/journals-permissions DOI: $10.1|77 /| 465$ | I6521।1009972

journals.sagepub.com/home/eup

@SAGE

\section{Laura Arnemann}

Department of Business, University of Mannheim, Mannheim, Germany

\section{Kai A Konrad}

Max Planck Institute for Tax Law and Public Finance, Munich,

Germany

\section{Niklas Potrafke $\mathbb{D}$}

Department of Economics, University of Munich, Munich, Germany; ifo Institute, Munich, Germany

\begin{abstract}
We examine whether collective memories on the aid and reform programs chosen to handle the 2010 European debt crisis differ between citizens from borrower and lender countries. We use new international survey data for non-experts and experts in member countries of the euro area. The results show that non-experts from borrower and lender countries remember aspects of the programs in different manners; indicating biases for assessments of how the crisis outcomes are perceived in borrower and lender countries. Nation-serving biases may well explain that the 2010 European debt crisis has reduced the sense of belonging rather than bringing European citizens closer together.
\end{abstract}

\section{Keywords}

Aid and reform programs, collective memories, 2010 European debt crisis, experts, nation-serving biases

\section{Corresponding author:}

Niklas Potrafke, ifo Institut - Leibniz-Institut für Wirtschaftsforschung an der Universität München e.V., Poschingerstraße 5, 81679 Munich, Germany.

Email: potrafke@ifo.de 


\section{Introduction}

The 2010 European debt crisis partitioned the countries of the euro zone into two groups: fiscal and financial market conditions dramatically deteriorated in some Euro area countries (for an account of the crisis see, e.g. Frieden and Walter, 2017, 2019; Schimmelfennig, 2015). Five countries (Greece, Ireland, Portugal, Spain and Cyprus) individually made formal applications for financial aid. These applications led to memoranda of understanding with the 'Troika', consisting of the European Commission, the International Monetary Fund and the European Central Bank. The memoranda contained two main aspects. The applicant country received loans or loan guarantees and had to agree to pursue structural reforms in its own economy under the supervision of the Troika. We refer to the countries that made formal applications as the 'borrower countries'. Other countries of the eurozone collectively used their fiscal credibility to provide these loans or guarantees and delegated the monitoring process on requested reforms in the borrower countries to the Troika. These countries are referred to as 'the lender countries'.

We examine how citizens from borrower and lender countries remember the European debt crises, the aid and reform programs, their motivation and their consequences. To this end, our study conducts two new international surveys. We used an internet survey tool (Prolific) to interview citizens in the eurozone countries and CESifo's World Economic Survey panel of experts (WES) to interview international economic experts. To our knowledge, this is the first systematical attempt to measure collective memories and differences in collective memories for borrower countries and lender countries for the 2010 European debt crisis and for its financial rescue missions. The study also compares the memories of eurozone citizens and expert economists from the eurozone.

The memories of citizens (non-experts) and experts turn out to differ quite a bit. The results show that non-experts from borrower countries had different memories than non-experts from lender countries. In their memories their own country group (borrower or lender country) appears in a favorable light. For example, nonexperts from borrower countries are 13.2 percentage points less likely to report that the lender countries wanted to help the borrower countries than non-experts from lender countries. In a similar vein, they are also 28 percentage points more likely to report that the lender countries were the main beneficiaries of the program. By contrast, the results do not suggest that experts from borrower countries remember the 2010 European debt crisis in a different manner than experts from lender countries.

To explain such differences, we refer to a finding in psychology according to which people care about self-image and manage to remember events in a way that makes them look more decent. A possible way in which this might happen is gradual transformation of memories over time. This makes our work related to studies in neuroscience and economic psychology approaches that deal with how memories on private credit relationships that transform over time (Dezső and Loewenstein, 2012), and collective memories (Roediger and Abel, 2015; 
Roediger et al., 2019). The source of resulting memory divergences can have several causes, which we cannot trace. These might include biases in nation-state media coverage, and such media effects might also interact with mental processes of memory formation.

The explanation of how citizens and experts perceive or remember aid and reform programs is related to the studies of attitudes of citizens or elites toward the European Union (EU) in general and toward the European Monetary Union (EMU). A large share of this literature finds that national economic consequences and personal economic benefits of integration contribute to individuals' EU approval rates. Objective economic indicators as well as their subjective perception can be relevant (Gabel and Palmer, 1995; Gabel and Whitten, 1997). Analogously, Xezonakis and Hartmann (2020) seek to identify economic explanations for the outcome of the bailout referendum in Greece in 2015, and Jurado et al. (2020) seek answers to the question why the EMU politically survived the 2010 European debt crisis. Economic motives and perceptions of alternative scenarios seemingly played a role. Negri et al. (2021) examine the integration effect and identity-building impact of the EMU. Economic aspects draw the dividing line between borrower and lender countries that we study, too. However, the argument is quite different and related to self-image concerns: a borrower appears more decent if help was offered to him, and if the helper is the main beneficiary of the lending contract, whereas the lender appears more decent if the lender was asked for the money and was motivated by altruistic motives to help.

We also contribute to the literature that investigates views of economic experts and nonexperts (e.g. Andre et al., 2019; Sapienza and Zingales, 2013) and show that economic experts and non-experts have different collective memories about the 2010 European debt crisis.

\section{Theory and hypotheses}

\section{Collective memories}

Theories about memory and its plasticity describe how individuals' memory is formed, kept, reactivated and changed over time, and how a self-serving bias manifests itself in individuals' memories. Dudai and Edelson (2016: 276) describe: 'When the memory is retrieved, it seems to re-enter a transient phase in which it again becomes susceptible to the same amnesic agents that were effective in the original consolidation window' (Dudai, 2012; Nader et al., 2000; Sara, 2000). Brain sciences suggest that memory enters a state of plasticity when it is reactivated and the copy that is then stored might differ from the one that has been activated (see Agren, 2014; Lee et al., 2017). Also, a tendency to memorize in a 'self-serving' way has been shown (see Bell et al., 2014). An important application in the context of informal credit relationships is the study by Dezső and Loewenstein (2012). Using data about informal credit relationships between relatives and friends, the authors find that borrowers' and lenders' recollections diverge on average and in a self- 
serving way about the credit event as such, the conditions of the loan they had agreed upon, and the loan performance.

The logic of self-serving memories cannot be applied straightforwardly to how citizens remember issues related to their nation. The lenders and borrowers in the 2010 European debt crisis are nations, not individuals, and the citizens we asked were not personally responsible for their countries' roles in the credit crisis. The formation of memories of individuals who belong to and identify with an individual nation might interact in more complicated ways. ${ }^{1}$ The multiple mechanisms and reinforcing effects that give rise to divergent memories of individual nations are difficult to separate from each other. ${ }^{2}$ Clearly, we cannot test hypotheses why collective memories differ. We will offer interpretations for why collective memories are likely to differ and the extent to which results are likely to suggest a nationserving bias.

Nation-serving collective memories of citizens may well influence cooperation and conflicts between states in a currency union, and in international politics more generally. Collective memories and own-nation-serving biases have been investigated in a few previous studies (e.g. Hirst et al., 2018). Much of the empirical work on nation-serving collective memories is on war and how aspects of it are remembered. Subjects overestimate their country's contribution to the Second World War (Roediger et al., 2019). Groups employ techniques such as selective omission, fabrication of alternative narratives and exaggeration or embellishments of events to let their group appear in a favorable light (Baumeister and Hastings, 2013). Common institutions inside a nation, such as common exposure to the same public media and other public institutions, might intensify information exchange inside the group, might strengthen and homogenize the national collections of memories and reinforce diverging views between countries (Rigney, 2018; Roediger and Abel, 2015).

H1: Citizens from borrower countries remember the 2010 European debt crisis in a different manner than citizens from lender countries.

\section{Experts and non-experts}

Scholars have examined for a long time whether elites and the general public view policy issues in similar ways. A prime example is European integration (see, for example, Gabel and Palmer, 1995; Hooghe, 2003). Elites have been favoring European integration to a larger extent than the general public. ${ }^{3}$ A major question is why. It is conceivable that both the elites respond to changing preferences of their electorates and that the elites make attempts to influence their electorate's preferences (e.g. Steenbergen et al., 2007). Since the 2010 European debt crisis, European citizens with a high education and many skills had more trust in government than citizens with a low education and less skills. Among borrower countries, citizens from countries that suffered from high unemployment rates had less 
trust in national governments than citizens from countries with lower unemployment rates (Foster and Frieden, 2017, 2021). ${ }^{4}$

Economic experts often evaluate economic policy issues in different manners than non-experts. Citizens were influenced by the views of economic experts, more so if the issue at stake is highly technical and less ideological (Johnston and Ballard, 2016). In the United States, for example, views between experts and non-experts differed especially on those issues on which economic experts had very homogeneous views (Sapienza and Zingales, 2013). Experts and non-experts have been shown to assess effects of macroeconomic shocks in different manners (Andre et al., 2019). People with a high degree of formal education and cosmopolitan communications maintain a more positive attitude towards European integration than people with a low degree of formal education and hardly any cosmopolitan communications (Inglehart, 1970). Expertise might be more developed among the economic experts, with less scope for a nation-serving adaptation of memories. Experts are likely to rely on sources of statistical evidence and on largely overlapping sets of research reports when forming their opinions. Also, national identity may be less pronounced among experts and overlaid by other identities, such as membership of an international elite, or a European identity. These factors suggest that national differences in assessments of the 2010 European debt crisis are less pronounced among experts than non-experts.

H2: Collective memories on the aid and reform programs chosen to handle the 2010 European debt crisis differ to a greater extent between non-experts than between experts from borrower and lender countries.

\section{Data}

Our data were obtained through international surveys that were conducted among two pools of participants. First, we asked economic experts from the World Economic Survey (WES) on their views about the financial entrenchment following the 2010 European debt crisis. The WES is a quarterly survey conducted by the ifo Institute. The survey includes many questions, indicating the opinion towards overall economic development from European and non-European experts such as economic growth and inflation. Furthermore, scholars used the WES to ask a limited number of one-off questions in individual survey waves (Andre et al., 2019; Boumans et al., 2018, 2021; Gründler and Potrafke, 2020a, 2020b; Mosler et al., 2019). Our questions on the 2010 European debt crisis were included in the WES survey in August 2018. We restrict our sample to include only experts who are currently living in the EU. Our sample includes 517 participants from EU member countries, among them 90 experts from program countries.

Second, we asked non-experts by using the website prolific.co. In contrast to other crowdsourcing platforms such as Mturk, Prolific is a platform specifically designed to recruit participants for academic research. ${ }^{5}$ In exchange for their 
participation in surveys or experiments, participants receive a financial reward. The survey was distributed to 1702 participants in August 2019, 498 of these participants came from program countries. To ensure that our participants had an opportunity to actively remember the events during the 2010 European debt crisis we restrict our sample to include only participants aged 25 or older. Both samples, for experts and non-experts, are not representative of the populations in the individual EU countries, however.

The same questions are used in both surveys, and in unchanged ordering. The individual questions and the country composition of survey participants for both samples are shown in the Online appendix. Of course, as the participants of the WES sample are mostly professional experts, respondents in both samples are unlikely to have similar socioeconomic characteristics. ${ }^{6} \mathrm{We}$ control for individual socioeconomic characteristics in the empirical analysis. We refer to the WES sample as the expert sample and to the Prolific sample as the non-expert sample.

\section{Empirical model}

We estimate the following model using logit estimation both for the sample of experts and the sample of non-experts:

$$
Y_{i j}=\alpha_{j}+\beta_{j} * D_{i}+\gamma_{j} * X_{i}+\varepsilon_{i j}
$$

$Y_{i j}$ describes the response of individual $i$ to question $j . Y_{i j}$ takes the value of one if a participant stated either strongly or slightly agree or if a participant stated the lender countries as the responsible party. The dummy variable $D_{i}$ indicates whether the respondents report to have the nationality of one of the borrower countries. We control for individual characteristics $X_{i}$ such as age, level of education, gender and employment status (affiliation for the expert sample). We report marginal effects of the dummy variable measuring whether a respondent has the nationality of one of the borrower countries. Including macro-economic variables that vary across individual countries is discussed as part of the robustness checks.

There may well be unobserved variables that are likely to be correlated with the respondents' answers and the borrower country dummy variable, our main explanatory variable. It is conceivable, for example, that the role of the media is quite important. First, the media in lender countries are likely to have reported about the 2010 European debt crisis in a different manner than the media in borrower countries (Müller et al., 2018). Second, media usage is very likely to vary a great deal across the individual respondents (and between experts and non-experts) and to be correlated with the individual answers. We do not have data at hand, however, that measure media coverage. 


\section{Results}

\section{Baseline results}

At the beginning of the survey, we ask the respondents to recall which countries signed memoranda of understanding. The central cluster of questions is about the assessments of these aid and reform programs. We first examine the respondents' perceptions about the general purpose of these programs: to help the borrower countries, to help the lender countries to avoid contagion, and/or to force institutional reforms upon the borrower countries. Related to the purpose of the aid and reform programs is the question of whether the borrower countries or the lender countries were considered the driving force behind these programs. And we ask about the assessments of which country group was the main beneficiary of the aid and reform programs.

We discuss the extent to which answers from non-experts and experts from borrower and lender countries differ. Figure 1 deals with reasons of why the lender countries entered the rescue program. Non-experts from borrower countries are 13.2 percentage points less likely to report that the lender countries wanted to

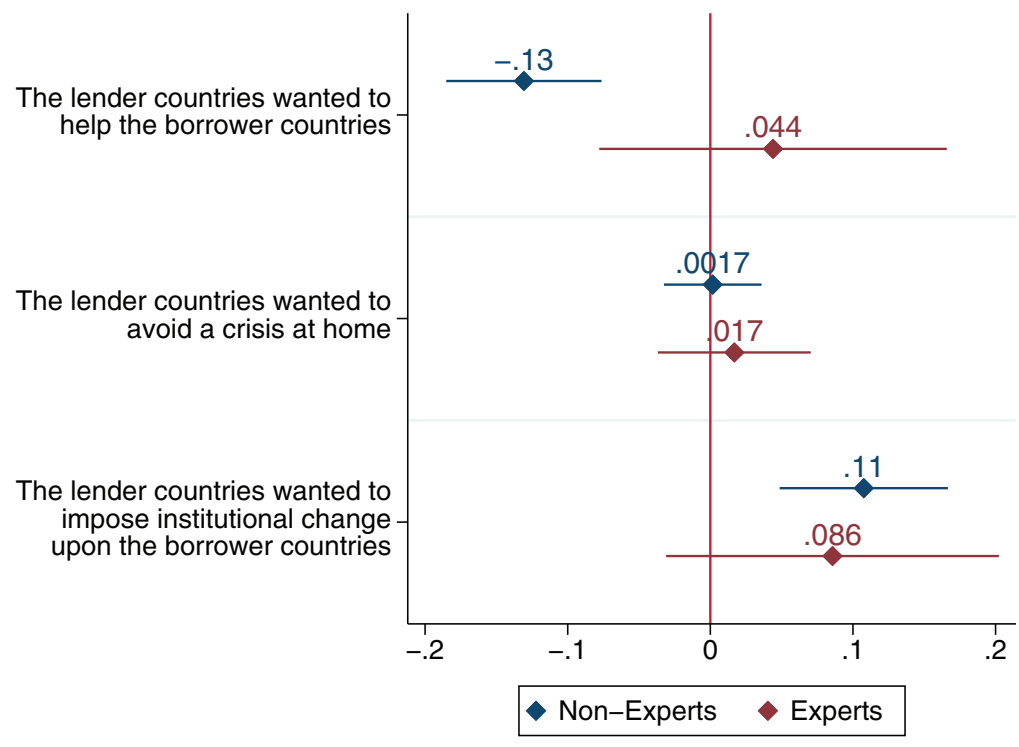

Figure I. Intentions of the lender countries.

Note: We display the average marginal effect of estimating our model by binary logit. The displayed effect is the effect of reporting to be a national of a program country. The diamonds show the size of the effect, the lines represent the $95 \%$ confidence intervals. The exact wording of the questions were the following: $2 a$ ) The lender countries wanted to help the borrowing countries; $2 b$ ) The lender countries wanted to help themselves avoid a crisis at home; $2 c$ ) The lender countries wanted to impose institutional change upon the borrower countries. The dependent variable takes the value of one when the individual respondent strongly or slightly agreed to the individual question and zero otherwise. 
help the borrower countries than non-experts from lender countries. The difference in assessments between non-experts from borrower and lender countries is large and statistically significant at the $1 \%$ level. By contrast, the assessments between experts from borrower and lender countries do not turn out to be statistically significant. Participants from borrower and lender countries agree that lender countries wanted to avoid a crisis at home both in the expert and non-expert sample $(62 \%$ of non-experts from lender countries agree that the lender countries wanted to force institutional change compared to $72 \%$ among the lender countries). We discuss descriptive statistics in the working paper version, see Arnemann et al., 2021. The marginal effects of the program dummy in the expert and nonexpert sample lack statistical significance. However, non-experts from borrower countries were 11 percentage points more likely to agree that the lender countries wanted to impose institutional change upon the borrower countries (Figure 1).

How can these differences be interpreted as own-nation serving? To address this question we concentrate on the results for the non-expert sample and consider the assessments about who mainly benefited from the aid and reform programs. As shown in Figure 2, non-experts from borrower countries are 28 percentage points more likely to report that the lender countries were the main beneficiaries of the program than non-experts from lender countries. This is compatible with each side

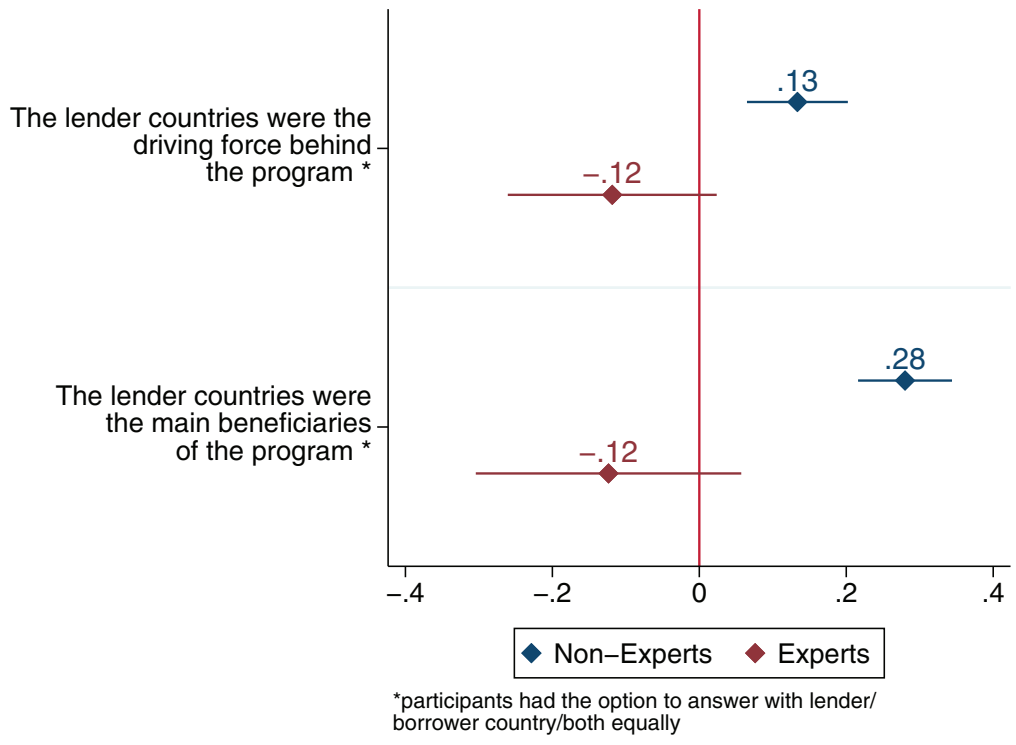

Figure 2. Who initiated and benefited from the rescue program.

Note: We display the average marginal effect of estimating our model by binary logit. The displayed effect is the effect of reporting to be a national of a program country. The diamonds show the size of the effect, the lines represent the $95 \%$ confidence intervals. The exact wording of the questions is the following: 3 ) Who was the driving force behind signing the memorandum? 4)Who was the main beneficiary of the program? The dependent variable takes the value of one when the respondent replied 'the lender countries'. 
inflating their contributions and costs and/or deflating their receipts or benefits an attitude which one might call own-nation serving. Differences are not statistically significant in the expert sample.

These views of being the generous helper fit well with the memory biases shown in Figure 1. A large share of respondents from the borrower countries answer in a way that is consistent with the following narrative. They were more likely to believe that the lender countries wanted to help themselves. They also tend to repress the idea that they were desperately in need of help and are more likely to entertain the idea that they did not push for help. Non-experts from borrower countries are 13 percentage points more likely to report that the lender countries were the driving force behind signing the memorandum than non-experts from lender countries (Figure 2), but were helped because the lender countries had no choice - they wanted to help themselves, and therefore 'wanted' to help (Figure 1).

The differences between respondents' answers in borrower countries and in lender countries in the expert group do not turn out to be statistically significant. It is conceivable, for instance, that there simply is no major memory bias among experts. Experts from different countries are informed by reading much of the same statistical material and scientific reports. And they might identify less with their own countries of origin and have a more cosmopolitan orientation. Therefore, the forces for developing a nation-bias might be less strong for experts than for non-experts. We address some of these issues below.

We now turn to a second set of questions (Figure 3). We ask whether the rescue experience might have caused feelings of guilt, feelings of being exploited, and/or feelings of inferiority in the borrower countries, and whether the populations in the lender countries are feeling exploited and/or disappointed. All these questions were presented to participants from all countries. We investigate whether the answers of participants from borrower countries and lender countries differ. If we find differences, they do not straightforwardly reflect a nation-serving bias but might rather be the outcome of such a bias. Figure 3 shows that the answers of non-expert respondents from borrower countries differ from those from lender countries. Participants from borrower countries in the non-expert sample are 9.2 percentage points more likely to agree that the program experience made them feel guilty and inferior. Further, the probability to agree to 'The rescue experience made many citizens in the borrower countries feel exploited' is 17 percentage points higher among non-experts from borrower countries. These marginal effects are statistically significant at the $1 \%$ level (Figure 3 ).

These differences are important in their own right, because they suggest country biases. An interpretation along the lines of nation-serving assessments is more complex and more difficult. A respondent from Greece might think that the aid and reform programs mainly benefited the lender countries who forced Greece to undertake the reforms. Hence, a Greek respondent might not feel guilty. On the other hand, a respondent from the lender countries might feel that the aid and reform programs were a benevolent gesture from the lender countries which provided large benefits to the program countries. Hence, a respondent from the lender 


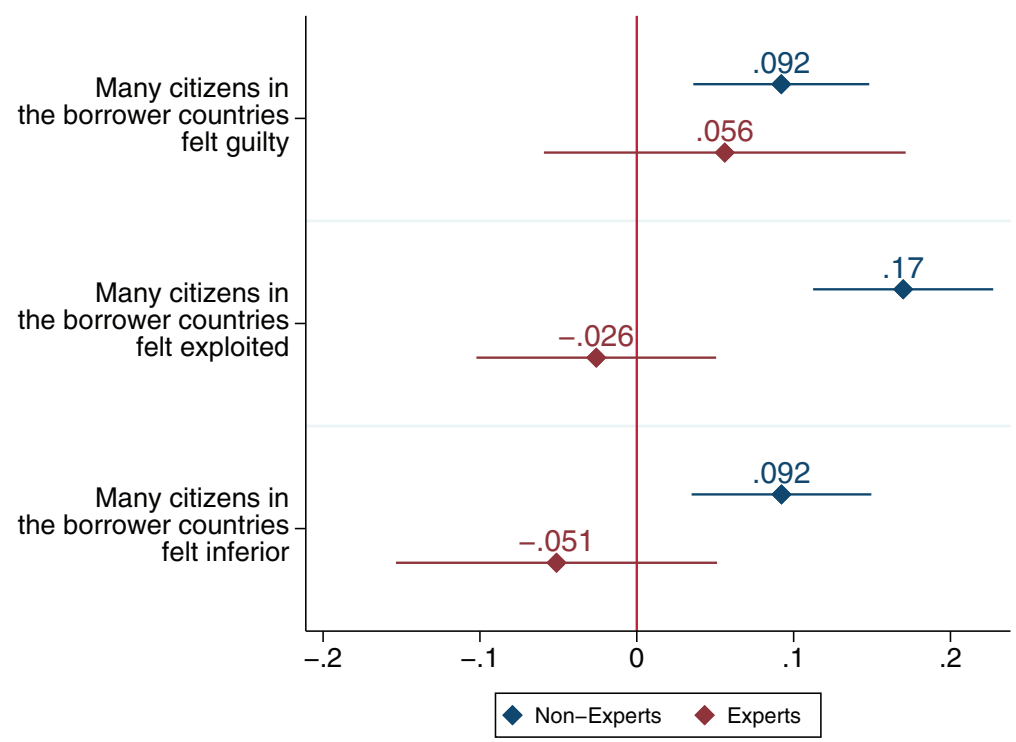

Figure 3. Sentiments among borrower countries.

Note: We display the average marginal effect of estimating our model by binary logit. The displayed effect is the effect of reporting to be a national of a program country. The diamonds show the size of the effect, the lines represent the $95 \%$ confidence intervals. The exact wording of the questions is the following: $5 \mathrm{a}$ ) The rescue experience made many citizens in the borrower countries feel guilty; $5 b$ ) The rescue experience made many citizens in the borrower countries feel exploited; $5 c$ ) The rescue experience made many citizens in the borrower countries feel inferior. The dependent variable takes the value of one when the individual respondent strongly or slightly agreed to the individual question and zero otherwise.

countries might be more prone to assume that citizens in the borrower countries felt guilt due to the large benefits they received. Also, the respondents' perceptions might be formed by direct observations in the countries or media reports, but their views about the reasons and motivations for aid and reform programs and their views about who actually benefited from these programs should correlate with their assessments and might affect their beliefs about these feelings. ${ }^{7}$

Similar questions measure the assessments in the groups of respondents about the feelings in the lender countries (Figure 4). In particular, we asked the participants whether they agree that the aid and reform programs made the citizens in the lender countries feel exploited and disappointed. We do not observe significant differences for respondents from the two country groups. The same applies for the differences in the views of experts from the two country groups. Perhaps not unexpected, and similar to the first set of questions, experts from borrower and lender countries answered in quite a similar manner. We also asked whether the rescue experience strengthened friendship between the citizens in the two groups of countries (Figure 4). The results do not suggest that respondents from borrower countries have different views than respondents from lender countries, but the 


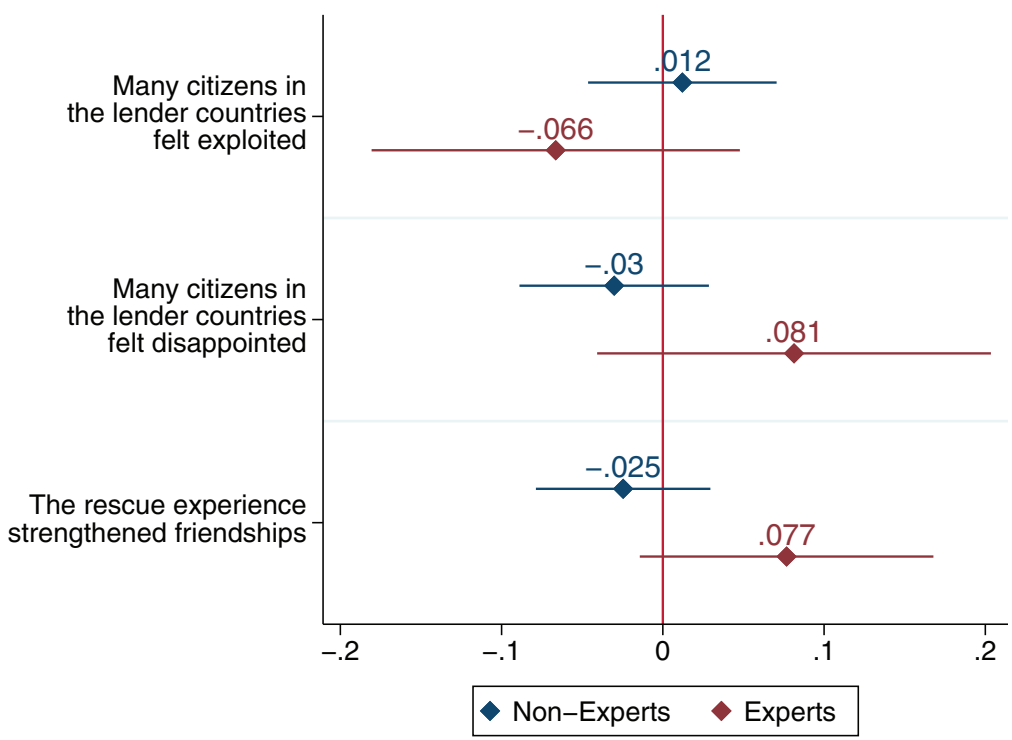

Figure 4. Sentiments among lender country citizens.

Note: We display the average marginal effect of estimating our model by binary logit. The displayed effect is the effect of reporting to be a national of a program country. The diamonds show the size of the effect, the lines represent the $95 \%$ confidence intervals. The exact wording of the questions is the following. $5 \mathrm{~d}$ ) The rescue experience made many citizens in the lender countries feel exploited; 5e) The rescue experience made many citizens in the lender countries feel disappointed; $5 f$ ) The rescue experience strengthened friendships between citizens. The dependent variable takes the value of one when the individual respondent strongly or slightly agreed to the individual questions and zero otherwise.

results draw a disappointing picture that is of interest in its own right. Building on realistic group conflict theory, an event such as the 2010 European debt crisis was a major challenge that was overcome by joint action. In the light of realistic group conflict theory (for a survey see Böhm et al., 2018; Sherif et al., 1961) it could have been a major opportunity for the governments of member countries to overcome cleavages and strengthen the friendship ties between the countries. However, only some $25 \%$ of the non-experts and some $20 \%$ of the experts believe that the aid and reform programs strengthened friendships (descriptive statistics are shown in the working paper version, see Arnemann et al., 2021). ${ }^{8}$ This is in line with the high percentage rates of all respondents who think that the crisis and its treatment caused feelings of exploitation, inferiority and disappointment.

The borrower countries were affected by the crisis in different manners. The 2010 European debt crisis first became manifest in Greece. Three extensive financial rescue packages and comprehensive reform programs were adopted and simultaneously accompanied by massive political protests. The resistance of the population in Greece was large and the consequences for the population were drastic (scholars examine the 2010 European debt crisis in Greece in detail; for 
example, Katsanidou and Otjes, 2016; Mink and de Haan, 2013; Mosler et al., 2019; Sinn, 2015). The salience of events in Greece might have caused a higher level of consensus among the lender and borrower countries about the situation in Greece. On the other hand, since Greece was by far the most affected country, there might be solidarity between the other lender countries and Greece. This invites a specific view on Greece (Figure 5). We only ask about Greece, since Greece remains the only country that has not repaid its debt.

When asked whether Greece will be capable of fully paying back its debt, citizens from program countries show a 13 percentage point higher likelihood to agree in the non-expert sample and a 12 percentage point higher likelihood in the expert sample. The effect in both samples is statistically significant at the $1 \%$ level. When asked about who benefited from the loans to Greece non-experts from the borrower countries are 20 percentage points more likely to state that lender countries benefited from the loans to Greece (Figure 5).

Both these divergences have natural interpretations as nation-serving biases. Respondents from the borrower countries might associate themselves with Greek citizens and perceive Greek citizens as more reliable borrowers than the respondents from lender countries. And respondents from borrower countries who

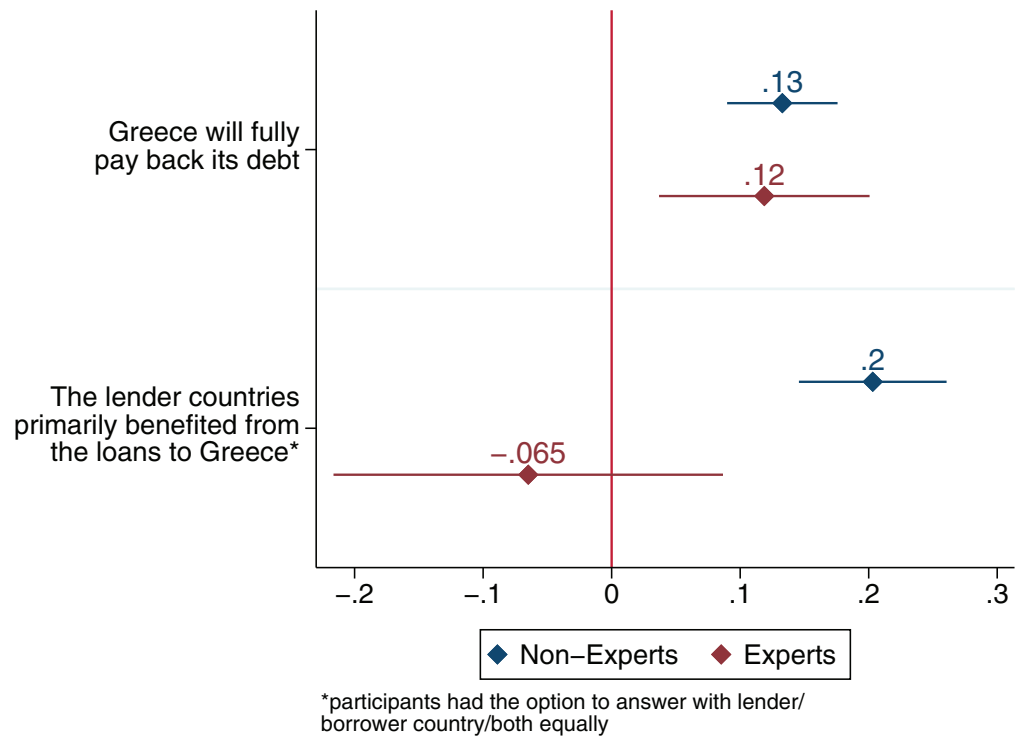

Figure 5. Situation in Greece.

Note: We display the average marginal effect of estimating our model by binary logit. The displayed effect is the effect of reporting to be a national of a program country. The diamonds show the size of the effect, the lines represent the $95 \%$ confidence intervals. The exact wording of the questions is the following. 6) Greece will fully pay back it's debt.; 7) Who primarily benefited from the loans to Greece? The dependent variable takes the value of one when the individual respondent strongly or slightly agreed to the individual questions or stated Greece and zero otherwise. 
had a similar experience as Greece are less inclined to interpret the aid and reform programs as benevolent acts of the helper countries for the benefit of Greece. They might be more inclined to think that the lenders' actions were guided by their selfinterest.

We also examine how answers differ between the citizens from the individual borrower countries. The results suggest that Greek citizens had somewhat different views than the citizens from the other borrower countries. The descriptive statistics are shown in Table 1.

Table I. Comparison of answers from borrower country citizens (non-experts).

Greece Ireland Portugal Spain France Germany Borrowers Lenders

2a. The lender countries wanted to help borrower countries
0.31
0.62
0.47
0.54
0.59
0.55
0.48
0.62

2b. The lender countries wanted to avoid crisis at home
0.96
0.93
0.88
0.86
0.94
0.94
0.90
0.90

2c. The lender countries wanted to force institutional change
0.87
0.54
0.77
0.66
0.70
0.52
0.72
0.62

5a. Borrower citizens felt guilty
$0.57 \quad 0.5 \mathrm{I}$
0.41
0.45
0.49
0.34
0.48
0.39

5b. Borrower citizens felt exploited
0.93
0.74
0.78
0.63
0.66
0.70
0.78
0.61

$5 c$. Borrower citizens felt inferior

$\begin{array}{llllllll}0.82 & 0.75 & 0.62 & 0.68 & 0.62 & 0.67 & 0.71 & 0.62\end{array}$

5d. Lender citizens felt exploited

$\begin{array}{llllllll}0.73 & 0.51 & 0.57 & 0.57 & 0.54 & 0.79 & 0.60 & 0.60\end{array}$

$5 e$. Lender citizens felt disappointed

$\begin{array}{llllllll}0.68 & 0.43 & 0.58 & 0.57 & 0.64 & 0.70 & 0.57 & 0.61\end{array}$

5f. The rescue experience strengthened friendships
0.10
0.35
0.30
$0.27 \quad 0.28$
0.16
0.25
0.27

3. Lender countries were main beneficiaries

$\begin{array}{llllllll}0.68 & 0.57 & 0.43 & 0.52 & 0.50 & 0.41 & 0.55 & 0.43\end{array}$

4. Lender countries were driving force

$\begin{array}{llllllll}0.85 & 0.70 & 0.73 & 0.5 I & 0.60 & 0.46 & 0.71 & 0.44\end{array}$

6. Greece will fully pay back its debt
$0.36 \quad 0.30$
0.31
$0.35 \quad 0.29$
0.13
0.33
0.18

7. Greeks benefited from rescue package to Greece

\begin{tabular}{ccccccccc}
$N$ & 0.87 & 0.44 & 0.49 & 0.44 & 0.48 & 0.41 & 0.56 & 0.36 \\
\hline & 100 & 99 & 100 & 100 & 98 & 99 & 404 & 1293 \\
\hline
\end{tabular}

Note: The table displays the responses for citizens from the individual borrower countries. For questions 2, 5 and 6, respondents could answer: 'strongly agree', 'slightly agree', 'slightly disagree', 'strongly disagree', or 'I don't know'. We exclude all respondents who answered with 'I don't know' and report the share of respondents that strongly and slightly agreed to the individual question. For questions 3,4 and 7, respondents could answer: 'the lender countries', 'both equally', 'the borrower countries', or 'I don't know'. We exclude all respondents who answered with 'I don't know' and report the share of respondents that stated lender countries. 


\section{Robustness checks}

Socioeconomic characteristics. An interesting question is which socioeconomic characteristics inherent to experts might explain why they do not show differences in memories. We use interaction effects based on a linear model to examine whether individual groups of participants have a stronger differences in memories than others.

Age might well influence the perception of historic events. We therefore examine whether the effect of living in a borrower country differs for participants above the age of 35 as compared to participants below the age of 35 . We find no statistically significant differences for citizens living in a borrower country above the age of 35 .

Participants with a high level of education might have different political attitudes or use different types of media than participants with a low level of education (Inglehart, 1970). We interact the program variable with a dummy variable indicating whether the respondents have completed or are currently completing tertiary education. For most responses there is no differential effect of living in a borrower country for participants with a higher level of education. Citizens with a higher level of education from borrower countries are more likely to agree that lender country citizens felt exploited.

We also investigate whether not living in one's country of birth influences the recollection of the 2010 European debt crisis. Bechtel et al. (2014) show that having a cosmopolitan attitude explains differences in the attitudes of German citizens towards the aid and reform program. Choosing residence in another country might be an indication of a more cosmopolitan attitude. But it might also be an indication of unclear or weaker national identities: it becomes unclear whether someone who migrated from one country to another country some years ago should show a nation bias in favor of the country of origin, or for the country of residence. And for either of the two we might expect a weaker identification with both of these countries. ${ }^{9}$

We find that most responses remain unchanged for respondents not living in their country of birth. For the assessment of whether Greece will pay back its debt and whether lender countries were the driving force the divergence between borrower and lender country citizens becomes smaller for the subsample of citizens living outside their country of birth. We interpret these results as being in line with the idea of own-nation biases.

Macroeconomic variables. We examine whether the correlation between the program country dummy variable and the respondents' answers depend on macroeconomic variables in the individual countries. We use interaction effects based on a linear model. Our macro variables include: the unemployment growth, public debt growth, gross domestic product (GDP) growth during the years after the great recession and the 2010 European debt crisis from 2007 to 2012. We also consider countries located more at the periphery (as measured by distance from Brussels). 
The baseline results remain unchanged when we condition the program country effect on these variables.

Non-experts from program countries who experienced large declines in GDP were more likely to agree that Greece will fully pay back its debt than non-experts from program countries who experienced small declines in GDP and low unemployment.

The effect of the program country dummy is somewhat smaller when the individual country was located closer to Brussels and when we use questions $4,5 \mathrm{~b}, 5 \mathrm{c}$ and 7 as the dependent variable.

Ordered and multinomial estimation. In the baseline model' the response options are aggregated into two categories, namely whether participants agree or do not agree with an individual statement. Differences between participants from non-program and program countries also emerge when the full likert scale is used as the dependent variable using multinomial and ordered logit models. For all questions in which participants were asked to rank their level of agreement, we estimate an ordered logit model. For questions in which participants were asked to name the responsible party, we estimate a multinomial logit model. Inferences do not change.

Inattentive respondents. When distributing the survey online, an attention check was included when asking non-experts about socioeconomic characteristics. All participants failing this attention check are excluded from the survey. Excluding all participants at the top $10 \%$ and bottom $10 \%$ of the survey time distribution does not change the inferences of the baseline estimation in the non-expert sample.

Clustered robust standard errors. We cluster standard errors on the country level. Due to the limited number of member states of the EU we adjust for the small number of clusters using the wild bootstrap method for logit regressions as suggested by Cameron and Miller (2015). Inferences change for some questions when applying this method (Roodman et al., 2019). The marginal effects of the borrower country dummy variable lack statistical significance, when we use the question about whether the lender countries wanted to force their desire for institutional change upon the borrower countries as the dependent variable.

Multiple hypothesis testing. Applying the Bonferroni Method to control for multiple hypothesis testing, the p-values can be adjusted by the number of questions that we ask our participants. Applying the Bonferroni correction does not change the inferences.

\section{The French-German divide}

Collective memories on the 2010 European public debt crisis may not just differ between respondents from borrower and lender countries. Brunnermeier et al. 
(2016) propose that the 2010 European debt crisis was a clash of ideas between France and Germany. ${ }^{10}$ We therefore examine whether the memories of respondents in France are more in line with the borrower countries and, in particular, differ from the memories of German respondents.

The memories of French and German non-experts differ for individual questions (Table 1). For example, $70 \%$ of the French and $52 \%$ of the German nonexperts agreed that the lender countries wanted to force institutional change in the borrower countries. The answers of French and German non-experts regarding this question diverged to a larger extent than the answers of non-experts from borrower $(72 \%)$ and lender countries $(62 \%)$. In a similar vein, 29\% of French and $13 \%$ of German non-experts agreed that the lender countries were the main beneficiaries of the aid and reform programs (33\% of the non-experts from borrower and $18 \%$ of the lender countries). Regarding other questions, however, the memories between French and German non-experts were more similar than the memories of non-experts from borrower and lender countries. For example, $66 \%$ of the French and $70 \%$ of the German non-experts agreed that the borrower countries felt exploited - this difference was much larger between non-experts from borrower $(78 \%)$ and lender countries $(61 \%)$.

The memories of French and German experts differ for individual questions to a large extent (Table 2). Standard errors are also larger than in the non-expert sample, however: our expert sample includes 31 French and 40 German experts; our non-expert sample includes 98 French and 99 German non-experts. In any event, $56 \%$ of the French and $82 \%$ of the German non-experts agreed that the lender citizens felt exploited - this difference was much larger between non-experts from borrower $(61 \%)$ and lender countries $(68 \%)$ and also much larger than the difference between French and German non-experts $(66 \%$ and $70 \%)$. What is more, $62 \%$ of the French and $30 \%$ of the German experts agreed that the lender countries were the driving force of the aid and reform programs $(40 \%$ among the experts from borrower and 52\% among the experts from lender countries).

We have also considered the view of Brunnermeier et al. (2016) in the multivariate analysis. We have considered France to be a program country and excluded Italy from the sample because Brunnermeier et al. (2016) propose that Italy was divided in a 'teutonic' north and a 'mediterranean' south. Doing so does not change the inferences as compared to our baseline model.

We have also examined differences between France, Spain, Greece, Portugal, Cyprus, the United Kingdom, Ireland, and Croatia ('mediterranean' countries) and Germany, Austria, Slovakia, Sweden, Finland, Denmark, the Netherlands, Estonia, Latvia, Lithuania, Poland and Czech Republic ('teutonic' countries). If we use the distinction between answers from respondents from 'mediterranean' countries and 'teutonic' countries as an explanatory dummy variable, differences as compared to our baseline model change. Doing so, however, does not distinguish between borrower and lender countries (the purpose of our study). 
Table 2. Comparison of answers from borrower country citizens (experts).

\begin{tabular}{|c|c|c|c|c|c|c|c|}
\hline Greece & Ireland & Portugal & Spain & France & Germany & Borrowers & Lenders \\
\hline \multicolumn{8}{|c|}{ 2a. The lender countries wanted to help borrower countries } \\
\hline 0.84 & 0.71 & 0.44 & 0.58 & 0.62 & 0.71 & 0.66 & 0.61 \\
\hline \multicolumn{8}{|c|}{ 2b. The lender countries wanted to avoid crisis at home } \\
\hline 1.00 & 1.00 & 0.94 & 0.96 & 0.93 & 1.00 & 0.98 & 0.96 \\
\hline \multicolumn{8}{|c|}{ 2c. The lender countries wanted to force institutional change } \\
\hline 0.82 & 0.63 & 0.82 & 0.88 & 0.79 & 0.73 & 0.83 & 0.75 \\
\hline \multicolumn{8}{|c|}{ 5a. Borrower citizens felt guilty } \\
\hline 0.40 & 0.67 & 0.41 & 0.30 & 0.35 & 0.23 & 0.38 & 0.32 \\
\hline \multicolumn{8}{|c|}{ 5b. Borrower citizens felt exploited } \\
\hline 0.96 & 1.00 & 0.72 & 0.83 & 0.93 & 0.94 & 0.86 & 0.88 \\
\hline \multicolumn{8}{|c|}{ 5c. Borrower citizens felt inferior } \\
\hline 0.75 & 0.89 & 0.67 & 0.71 & 0.96 & 0.94 & 0.73 & 0.78 \\
\hline \multicolumn{8}{|c|}{ 5d. Lender citizens felt exploited } \\
\hline 0.71 & 0.44 & 0.53 & 0.63 & 0.56 & 0.82 & 0.61 & 0.68 \\
\hline \multicolumn{8}{|c|}{ 5e. Lender citizens felt disappointed } \\
\hline 0.78 & 0.67 & 0.67 & 0.86 & 0.73 & 0.65 & 0.77 & 0.69 \\
\hline \multicolumn{8}{|c|}{ 5f. The rescue experience strengthened friendships } \\
\hline 0.19 & 0.14 & 0.44 & 0.15 & 0.11 & 0.03 & 0.24 & 0.16 \\
\hline \multicolumn{8}{|c|}{ 3. Lender countries were main beneficiaries } \\
\hline 0.50 & 0.17 & 0.31 & 0.70 & 0.67 & 0.46 & 0.50 & 0.62 \\
\hline \multicolumn{8}{|c|}{ 4. Lender countries were driving force } \\
\hline 0.40 & 0.40 & 0.22 & 0.67 & 0.62 & 0.30 & 0.40 & 0.52 \\
\hline \multicolumn{8}{|c|}{ 6. Greece will fully pay back its debt } \\
\hline 0.63 & 0.00 & 0.00 & 0.28 & 0.27 & 0.05 & 0.30 & 0.16 \\
\hline \multicolumn{8}{|c|}{ 7. Greeks benefited from rescue package to Greece } \\
\hline 0.36 & 0.40 & 0.67 & 0.56 & 0.64 & 0.44 & 0.50 & 0.57 \\
\hline 26 & 9 & 18 & 32 & 31 & 40 & 88 & 350 \\
\hline
\end{tabular}

Note: The table displays the responses for citizens from the individual borrower countries. For questions 2,5 and 6 respondents could answer: 'strongly agree', 'slightly agree', 'slightly disagree', 'strongly disagree', or 'I don't know'. We exclude all respondents who answered with I don't know and report the share of respondents that strongly and slightly agreed to the individual question. For questions 3, 4 and 7 respondents could answer: 'the lender countries', 'both equally', 'the borrower countries', or 'I don't know'. We exclude all respondents who answered with 'I don't know' and report the share of respondents that stated lender countries.

Overall, our results corroborate the hypothesis by Brunnermeier et al. (2016) that French and German respondents had different views regarding individual memories of the 2010 European debt crisis. Also, the memories of French respondents and the memories of the respondents from borrower countries were more similar than the memories of German respondents and the memories of the respondents from borrower countries. 


\section{Conclusion}

Economic psychology suggests that individual borrowers and lenders remember informal credit relationships in different manners: memories are influenced by a self-serving bias. Similar phenomena are reported in the context of major other international events for collective memories in different countries, the Second World War being an important example (Roediger et al., 2019).

We examine citizens' views about the 2010 European debt crisis. In particular, we investigate how the policy measures taken during the 2010 European debt crisis are remembered and whether there are systematic differences between citizens from borrower countries and citizens from lender countries. The results show differences in memories 8-9 years after the crisis.

Distinguishing between experts and non-experts, the results suggest that experts from lender and borrower countries have quite similar views about the 2010 European debt crisis. The views of non-experts are, by contrast, influenced by the country group of origin, and this influence may well be interpreted as a nation-serving bias.

Such biases may explain if the 2010 European debt crisis has reduced the sense of belonging rather than bringing European citizens closer together. This experience is also useful for future assistance activities within the EU as the ones discussed to handle the COVID-19 pandemic.

Differences in memories regarding the 2010 European debt crisis also occurred between French and German respondents (Brunnermeier et al., 2016). In particular, French and German experts had different memories regarding individual aspects of the crisis. An example is that French experts were more likely to agree that the lender countries were the driving force of the aid and reform program than German experts. Overall, the memories of French respondents and the memories of the respondents from borrower countries were more similar than the memories of German respondents and the memories of the respondents from borrower countries. Clearly, France and Germany are key players in the EU. Undertakings within the EU are more likely, the more France and Germany agree.

Our study did not consider the role of media and the narrative of national politicians. The media and the narrative of national politicians are likely, however, to influence collective memories. The study by Müller et al. (2018) shows, that leading newspapers in Germany, France, Italy and Spain blamed (or did not blame) individual countries for the 2010 European debt crisis. The narrative of national politicians is also very likely to influence collective memories: when national politicians blame individual countries for the crisis or downplay public debt, citizens are likely to adopt those views (Blesse et al., 2020b). Future research may therefore examine in more detail why collective memories on the 2010 European debt crisis differ.

\section{Authors' contribution}

K.K. and N.P. conceptualised the research question; L.A. conducted the empirical analysis. The remainder of the work was shared equally. 


\section{Acknowledgements}

We would like to thank Jana Cahlikova, Klaus Gründler, Christa Manta, Felix Rösel, Gerald Schneider, Heinrich Ursprung, Lisa Windsteiger, four anonymous referees, and the participants of the MPG Workshop on Political Economy and Public Finance 2019, the CESifo Area Conference on Macroeconomics and Survey Data 2020 and the meeting of the Verein für Socialpolitik 2020 for helpful comments. Armin Hackenberger and Philipp Heil provided excellent research assistance.

\section{Funding}

The author(s) received no financial support for the research, authorship, and/or publication of this article.

\section{ORCID iD}

Niklas Potrafke (D) https://orcid.org/0000-0001-5472-5507

\section{Notes}

1. For recent cognitive science contributions describing the possible channels, see (Gagnepain et al., 2020; Geana et al., 2019; Stone and Jay, 2019).

2. Posttraumatic events also influence memories (de Quervain et al., 2012).

3. Citizens with a high education tend to favor trade openness and globalization to a larger extent than citizens with a low education (see, for example, Egger and Fischer, 2020; Harms and Schwab, 2019, 2020; Mayda and Rodrik, 2005).

4. Bailouts were also negatively associated with satisfaction with democracy (see Schraff and Schimmelfennig, 2019).

5. Peer et al. (2017) show that participants from the platform Prolific perform better than participants from other crowdsourcing platforms.

6. The majority of participants from the Prolific sample, around $65 \%$ are younger than 35 , whereas the majority of participants from the WES sample are between 35 and 55. Participants from the WES sample also have a higher level of education than participants from the Prolific sample, $60 \%$ of participants hold a $\mathrm{PhD}$. Nonetheless the majority of participants from the Prolific sample have completed tertiary education. More than $80 \%$ of WES participants are male, whereas in the Prolific sample there is an equal share of men and women.

7. Our findings may also be interpreted in an alternative way. Having a self-serving or nation-serving bias might make individuals oblivious to the way policies are received in other countries. Dezső and Loewenstein (2012) refer to this phenomenon as having a 'blind spot' regarding the other party's feelings and emotions. The hypothesis on the existence of such a 'blind spot' is confirmed in our findings. Citizens from borrower countries are more likely to agree that they felt guilty, exploited and/or inferior as a consequence of the aid and reform programs. The largest difference between lender and borrower countries occurs with regards to feeling exploited: citizens from borrower countries were 17 percentage points more likely to agree that many citizens in the borrower countries felt exploited (Figure 3). 
8. Due to a typesetting error in the expert survey, this question was displayed as 'The rescue experience strengthened friendship ties between borrower'. The fraction of experts who answered this question with 'I don't know' lies at $20 \%$. This is very much in line with the frequency of 'I don't know' responses throughout the survey. Hence, it seems plausible that participants correctly understood the question.

9. Overall 541 non-experts reported living in a different country than their country of birth. 437 of these non-experts are from borrower countries and 104 are from lender countries. This information on whether respondents were born in a country other than that in which they currently live can be used as a proxy measure of country allegiance. The fraction of respondents living in a different country than their country of birth is quite equally distributed among borrower countries. For lender countries, the highest fraction of mobile participants come from Eastern European countries.

10. Blesse et al. (2020a) examine preferences of French and German politicians regarding EMU reforms. On governments' position taking in the 2010 European debt crisis, see Armingeon and Cranmer (2018).

\section{References}

Agren T (2014) Human reconsolidation: A reactivation and update. Brain Research Bulletin 105: 70-82.

Andre P, Pizzinelli C, Roth C, et al. (2019) Subjective models of the macroeconomy: Evidence from experts and a representative sample Available at: https://papers.ssrn. com/sol3/papers.cfm?abstract_id $=3355356$ (accessed 15 April 2021).

Armingeon K and Cranmer S (2018) Position-taking in the euro crisis. Journal of European Public Policy 25(4): 546-566.

Arnemann L, Konrad KA and Potrafke N. (2021) Collective memories on the 2010 European debt crisis. CESifo Working Paper No. 8825.

Baumeister RF and Hastings S (2013) Distortions of collective memory: How groups flatter and deceive themselves. In: Collective memory of political events. London: Psychology Press, pp.289-306.

Bechtel M, Hainmueller J and Margalit Y (2014) Preferences for international redistribution: The divide over the eurozone bailouts. American Journal of Political Science 58(4): 835-856.

Bell R, Schain C and Echterhoff G (2014) How selfish is memory for cheaters? Evidence for moral and egoistic biases. Cognition 132(3): 437-442.

Blesse S, Bordignon M, Boyer P, et al. (2020b). The future of the European project: Survey results from members of national parliaments in France, Italy and Germany. CEPRDP 15021.

Blesse S, Boyer P, Heinemann F, et al. (2020a) European monetary union reform preferences of French and German parliamentarians. European Union Politics 20(3): 406-424.

Böhm R, Rusch H and Baron J (2018) The psychology of intergroup conflict: A review of theories and measures. Journal of Economic Behavior \& Organization 178: 947-962.

Boumans D, Garnitz J and Schulze GG (2018) Who has terror angst? Perceptions of the effects of terror on the world economy. Applied Economics Letters 25(1): 29-33.

Boumans D, Gründler K, Potrafke N, et al. (2021) The global economic impact of politicians: Evidence from an international survey RCT. CESifo Working Paper No. 8833.

Brunnermeier MK, James H and Landau J-P (2016) The Euro and the Battle of Ideas. Princeton, NJ: Princeton University Press. 
Cameron AC and Miller DL (2015) A practitioner's guide to cluster-robust inference. Journal of Human Resources 50(2): 317-372.

de Quervain DJ-F, Kolassa I-T, Ackermann S, et al. (2012) Pkc is genetically linked to memory capacity in healthy subjects and to risk for posttraumatic stress disorder in genocide survivors. PNAS 109: 8746-8751.

Dezső L and Loewenstein G (2012) Lenders' blind trust and borrowers' blind spots: A descriptive investigation of personal loans. Journal of Economic Psychology 33(5): 996-1011.

Dudai Y (2012) The restless engram: Consolidations never end. Annual Review of Neuroscience 35(1): 227-247.

Dudai Y and Edelson MG (2016) Personal memory: Is it personal, is it memory? Memory Studies 9(3): 275-283.

Egger H and Fischer C (2020) Increasing resistance to globalization: The role of trade in tasks. European Economic Review 126: 103446.

Foster C and Frieden J (2017) Crisis of trust: Socio-economic determinants of Europeans' confidence in government. European Union Politics 18(4): 511-535.

Foster C and Frieden J (2021) Economic determinants of public support for European integration, 1995-2018. European Union Politics. https://doi.org/10.1177/ 1465116521994181

Frieden J and Walter S (2017) Understanding the political economy of the eurozone crisis. Annual Review of Political Science 20(1): 371-390.

Frieden J and Walter S (2019) Analyzing inter-state negotiations in the eurozone crisis and beyond. European Union Politics 20(1): 134-151.

Gabel M and Palmer H (1995) Understanding variation in public support for European integration. European Journal of Political Research 27(1): 3-19.

Gabel M and Whitten GD (1997) Economic conditions, economic perceptions, and public support for European integration. Political Behavior 19(1): 81-96.

Gagnepain P, Vallée T, Heiden S, et al. (2020) Collective memory shapes the organization of individual memories in the medial prefrontal cortex. Nature Human Behaviour 4(2): 189-200.

Geana A, Duker A and Coman A (2019) An experimental study of the formation of collective memories in social networks. Journal of Experimental Social Psychology 84: 103813.

Gründler K and Potrafke N (2020a) Experts and epidemics. CESifo Working Paper No. 8556.

Gründler K and Potrafke N (2020b) Fiscal rules: Historical, modern, and sub-national growth effects. CESifo Working Paper 8305.

Harms P and Schwab J (2019) Like it or not? How the economic and institutional environment shapes individual attitudes towards multinational enterprises. The World Economy 42(3): 636-679.

Harms P and Schwab J (2020) Depression of the deprived or eroding enthusiasm of the elites: What has shifted the support for international trade? European Journal of Political Economy 64: 101901.

Hirst W, Yamashiro JK and Coman A (2018) Collective memory from a psychological perspective. Trends in Cognitive Sciences 22(5): 438-451.

Hooghe L (2003) Europe divided? Elites vs. public opinion on European integration. European Union Politics 4(3): 281-304.

Inglehart R (1970) Cognitive mobilization and European identity. Comparative Politics 3(1): 45-70. 
Johnston CD and Ballard AO (2016) Economists and public opinion: Expert consensus and economic policy judgments. Journal of Politics 78(2): 443-456.

Jurado I, Walter S, Konstantinidis N, et al. (2020) Keeping the euro at any cost? Explaining attitudes toward the euro-austerity trade-off in Greece. European Union Politics 21(3): 383-405.

Katsanidou A and Otjes S (2016) How the European debt crisis reshaped national political space: The case of Greece. European Union Politics 17(2): 262-284.

Lee JL, Nader K and Schiller D (2017) An update on memory reconsolidation updating. Trends in Cognitive Sciences 21(7): 531-545.

Mayda AM and Rodrik D (2005) Why are some people (and countries) more protectionist than others? European Economic Review 49(6): 1393-1430.

Mink M and de Haan J (2013) Contagion during the Greek sovereign debt crisis. Journal of International Money and Finance 34: 102-113.

Mosler M, Potrafke N and Reischmann M (2019) How to handle in fiscal crisis in Greece: Empirical evidence based on a survey of economic experts. Fiscal Studies 40(3): 375-399.

Müller H, Porcaro G and von Nordheim G (2018) Tales from a crisis-diverging narratives of the euro area. Policy Contributions 24228, Bruegel.

Nader K, Schafe GE and Le Doux JE (2000) Fear memories require protein synthesis in the amygdala for reconsolidation after retrieval. Nature 406(6797): 722-726.

Negri F, Nicoli F and Kuhn T (2021) Common currency, common identity? The impact of the euro introduction on European identity. European Union Politics 22(1): 114-132.

Peer E, Brandimarte L, Samat S, et al. (2017) Beyond the Turk: Alternative platforms for crowdsourcing behavioral research. Journal of Experimental Social Psychology 70: $153-163$.

Rigney A (2018) Remembrance as remaking: Memories of the nation revisited. Nations and Nationalism 24(2): 240-257.

Roediger HL and Abel M (2015) Collective memory: A new arena of cognitive study. Trends in Cognitive Sciences 19(7): 359-361.

Roediger HL, Abel M, Umanath S, et al. (2019) Competing national memories of world war II. Proceedings of the National Academy of Sciences 116(34): 16678-16686.

Roodman D, Nielsen MØ, MacKinnon JG, et al. (2019) Fast and wild: Bootstrap inference in Stata using boottest. The Stata Journal: Promoting Communications on Statistics and Stata 19(1): 4-60.

Sapienza P and Zingales L (2013) Economic experts versus average Americans. American Economic Review 103(3): 636-642.

Sara S (2000) Retrieval and reconsolidation: Toward a neurobiology of remembering. Learning \& Memory 7(2): 73-84.

Schimmelfennig F (2015) Liberal intergovernmentalism and the euro area crisis. Journal of European Public Policy 22(2): 177-195.

Schraff D and Schimmelfennig F (2019) Eurozone bailouts and national democracy: Detachment or resilience? European Union Politics 20(3): 361-383.

Sherif M, Harvey O, Jack White B, et al. (1961) The Robbers Cave Experiment: Intergroup Conflict and Cooperation. Vol. 10. Norman, OK: Institute of Group Relations, University of Oklahoma.

Sinn H-W (2015) The Greek tragedy. CESifo Forum 16: 5-35. 
Steenbergen MR, Edwards EE and de Vries CE (2007) Who's cueing whom? Mass-elite linkages and the future of European integration. European Union Politics 8(1): 13-35.

Stone CB and Jay AC (2019) From the individual to the collective: The emergence of a psychological approach to collective memory. Applied Cognitive Psychology 33(4): 504-515.

Xezonakis G and Hartmann F (2020) Economic downturns and the Greek referendum of 2015: Evidence using night-time light data. European Union Politics 21(3): 361-382. 